\title{
Electronic vs. Print Resources: A Survey of Perception, Usage and Preferences Among Central University Undergraduate Students
}

\author{
George Clifford Yamson \\ Faculty of Law Library, Central University, Ghana \\ Antonia B. Appiah \\ Balme Library, University of Ghana, Legon, Ghana \\ Dr. Marian Tsegah \\ Communication Studies Department, Central University, Ghana
}

Doi: 10.19044/esj.2018.v14n7p291 URL:http://dx.doi.org/10.19044/esj.2018.v14n7p291

\begin{abstract}
The study adopted a cross-sectional survey approach to examine the perception, usage and preferences of electronic and print resources among University Students. The study sought to determine the knowledge of students on electronic library resources, their value for electronic and print resources, ascertain the perceived usefulness, perceived ease of use, and intended use these resources. Results from the study indicated that majority 134(57.0\%) of the respondents always preferred print resources format for their academic work while 101(43\%) occasionally preferred the electronic resource format for academic work. The findings of the study are critical to the implementation of policies and procedures geared toward sensitizing students, faculty and other stakeholders to the benefits of increasing students' knowledge and use of electronic library resources. The study is envisaged to aid in strategic planning and investments pertaining to these resources and provide recommendations to improve knowledge and use of these resources within university.
\end{abstract}

Keywords: Library resources, students

\section{Introduction}

Electronic databases form a common part of the suite of information products offered by most academic libraries (Lang, 2008). They provide access to a spectrum of information formats, mainly CD-ROM, e-book, e-journal, OPACs and Internet. Although journals are most strongly covered in subject, databases also provide access to newspaper articles, books, theses and dissertations, maps, conference papers, and abstracts, book reviews, patents, standards, images, statistics and research reports (Vzarach, 2011). According 
to Sahin, Balta \& Ercan (2010) academic journals databases provides a rich source of specialized information and are widely used by many academics and students; they are essential reference tools for these people for detailed research into different subject areas and are grouped into subjects according to the different disciplines.

Liu (2004) posited that the proliferation of electronic resources and digital libraries have as of now affected and changed the way students and researchers utilize print resources and traditional libraries. It has started another flood of writing on the perceptions and preferences of print and electronic resources. College students, graduate students, and faculty have distinctive perceptions and preferences in their decisions about print and electronic resources. Cumaoglu, Sacici \& Torun (2013) have rightly observed that in this age most printed resources are being supplanted with electronic version and the propensities identified with daily paper, magazine, course material and book reading have experienced changes. Thus, the habits of some lecturers and the current crop of University students born in the $21^{\text {st }}$ century further demonstrate this variance (Cumaoglu et al., 2013).

Central University like most university libraries in Ghana, subscribe to a number of E-resources e-journal (e-books), in a number of different formats from a variety of vendors through the Consortium of Academic and Research Libraries in Ghana (CARLIGH). The Central University has been a member of the (CARLIGH) for close to ten years, with its library regularly subscribing to electronic journals and databases. The library staff also make conscious effort to teach and encourage students to utilize these e-resources for their academic and research works; through orientation and information literacy classes.

However, Bamidele, Omeluzor \& Amadi, (2013) observed that there was a clear disparity between the annual subscription fee of journals and utilization by the undergraduate students. Indeed, the Central University cannot be exempted from this assertion. Despite the huge investment and subscription cost on the university's budget and the effort made by the Eresource librarian for students to use the resources, records from Emerald Usage Statistics alone for 2016 academic year with 2806 downloads gives a hint that students do not utilize journal publications for their research work and mostly resort to either Google or other printed resources. Again, another problem faced by Central University is the situation where the library does not have its own permanent structure. Corlett-Rivera \& Hackman (2014) confirm, "Like most university libraries, we face space constraints and other factors that increasingly pressure us to purchase a significant portion of our collection in electronic form, rather than in print". With these problems highlighted above, the purpose of this paper is to gather data on perception, usage and preferences 
of electronic and print resources choices among undergraduate students of Central University

\section{Theoretical Framework}

This study examines the perception, usage and preferences of electronic and print resources among undergraduate students of Central University. The ability of students to use electronic resources or print sources, purpose and satisfaction level of students with the use of electronic or print resources are critical issues to this study. This work is based on theories that would emphasize use of electronic resources. Theories that are relevant to this study include: Technology Acceptance Model by Davis (1989), Roger's Diffusion of innovations (1995), Productivity Theory, Input output model, system model etc.

\section{Technology Acceptance Model (TAM)}

The Technology Acceptance Model (TAM) models how users accept and use new technology. The model describes the factors that influence users' decisions about how and when they will use new technology, notably:

Perceived usefulness (PU) - This was defined by Fred Davis as "the degree to which a person believes that using a particular system would enhance his or her job performance".

Perceived ease-of-use (PEOU) - Davis defined this as "the degree to which a person believes that using a particular system would be free from effort" (Davis 1989).

The TAM has been continuously studied and expanded. The two major upgrades are the TAM 2 (Venkatesh \& Davis 2000 \& Venkatesh 2000) and the Unified Theory of Acceptance and Use of Technology (or UTAUT, Venkatesh et al. 2003).

Several researchers have replicated Davis's study to provide evidence on the relationships between usefulness, ease of use, and system use (Adams, Nelson \& Todd 1992; Davis 1989; Hendrickson, Massey \& Cronan 1993; Segars \& Grover 1993; Subramanian 1994; Szajna 1994). Attention has focused on testing the questionnaire used by Davis. Adams et al. (1992) replicated the work of Davis to demonstrate the validity and reliability of the instrument and measurement scales. Hendrickson, et al., (1993) found high reliability and good test-retest reliability. Szajna (1994) found the instrument valid.

The basic tenets of this theory are that the invention of new technology can alter the way society responds to events or what they use to do in an old way. 


\section{Literature Review}

\section{Use of e-resources among students}

"Electronic resources" refer to those materials that require computer access, whether through a personal computer, mainframe, or handheld mobile device. They may either be accessed remotely via the Internet or locally. Some of the most frequently encountered types are:

E-journals, E-books, Fulltext (aggregated) databases, Numeric and statistical databases E-images and E-audio/visual resources (IFLIA, 2012).

The levels of utilization of e-resources in universities differ despite the huge investments in journal subscription (Bamidele, Omeluzor and Amadi, 2013). Ogunniyi, Akerele, and Afolabi (2011) stated that of all the serials subscribed to by any library, journals are the most important to researchers because much of the articles therein are products of research and it may never appear in any other publications.

Cason and Scoyoc (2006) studied the undergraduate students' research habits in a strictly electronic library environment at a large public university and found out that the undergraduate students in the electronic library relied primarily on Internet sites and online instruction modules (for example Blackboard or WebCT) for their research needs rather than university-funded research sources. Ogunniyi, Akerele and Afolabi (2011) investigated the use of serial publications by the academic staff of School of Arts and Social Sciences in Adeyemi College of Education, Ondo State, Nigeria. The researchers found out that $66.7 \%$ of the respondents used the serial section while $33.3 \%$ did not. Majority of the respondents, $21(70 \%)$ used the serial section for research purpose while 1(3.3\%) used it for relaxation and be acquainted with current information.

Bamidele et al., (2013) asserted that the use of print journals is drastically reducing among undergraduate students in some higher institution of learning. Hampton-Reeves, Mashiter, Westaway, Lumsden, Day, Hewertson, and Hart (2009) identified the consistency of students on the use of Google to save themselves the trouble of going to the library. Hammed and Osunrinade (2010) also found out that $64.8 \%$ of undergraduate students who responded in their study preferred to use text books against $22.1 \%$ who used journal. This implied that students perceive textbook and online search engines as the best options to access information for their research work.

\section{Use of electronic resources in developed countries Use of electronic resources in developed countries}

The use of electronic databases in developed countries varies from one developed country to another. For instance, students report different levels of use of electronic databases, as well as different purposes. A study by Romanov \& Aarnio (2006) with 837 medical and dental students at the University of 
Helsinki, Finland found that twenty-four percent of medical students and nineteen percent of dental students searched MEDLINE for study purposes, and thirty-two percent and twenty-four per cent respectively for research purposes. The authors also found that full-text articles were used by (23\%) of medical students and (10\%) of dental students. (12\%) of respondents never utilized either MEDLINE or full-text articles (Romanov and Aarnio, 2006).

Another study in IRAN by Anaraki, and Babalhavaeji (2013) found that the utilization level of students in three universities, that is, Tehran University of Medical Science (TUMS), Iran University of Medical Science (IUMS) and Shahid Beheshti Medical University (SBMU) were lower than the average and those who are not aware of the existence of the Integrated Digital Library (IDL) portal used general search engines to meet their information needs. According to their findings, students of Tehran University of Medical Science (TUMS) used EndNote, Elsevier, Thomson, Scopus and ProQuest databases most (Anaraki \& Babalhavaeji, 2013). The authors also carried out a similar study in Iraq and found that the utilisation level of students in the universities were lower than average (Anaraki and Babalhavaeji (2013). Also, Iran, Shabani, Naderikharaji and Abedi (2011) found that the amount of reading of electronic databases is highest among students who read technical and engineering subjects. The authors again revealed that doctoral students usually make use of electronic databases, whereas postgraduate students generally print out more electronic database documents.

Currently it seems as if interest in the use of databases is stronger in developing countries (e.g. Hadebe \& Hoskins, 2010; Ingutia-Oyieke \& Dick, 2010; Lwehabura, 2008; Makori, 2015; Mawindo \& Hoskins 2008). This could be attributed to spiralling interest in technology use among undergraduate students.

Okello-Obura and Magara (2008) investigated electronic information access and utilisation at the East African School of Library and Information Science, Makerere University, Uganda. Out of the 250 targeted students, 190 responded, giving a response rate of $76 \%$. The study discovered that users derived a lot of benefit from electronic resources, gaining access to a wider range of information and improved academic performance as a result of access to quality information. Bhat and Mudhol (2014) also found that students' attitudes seem to be very positive towards electronic databases for their study and research. Their study revealed that students heavily depend on electronic databases for their required information and to keep themselves up-to-date in their subject area.

In a study in the Punjab State of India, Manhas (2008) found in a survey of dental students that the use of electronic resources in order of preference was as follows; e-books (43.6\%), electronic databases (34.5\%), DVD/CDROMs $(16.3 \%)$ and other electronic resources $(7 \%)$. Another similar related 
study in India by Naqvi (2012) revealed that very large majorities (70\%) of the postgraduate students were well aware about the available databases and they also used these for their different purposes. Also a study by Dhanavandan (2012) regarding access to and awareness of ICT resources and services in the Medical College Libraries in Puducherry (country) discovered that (87.33\%) of the respondents used electronic databases for the purpose of their research, while $(61.33 \%)$ of the respondents use it for communication purpose, $(54.66 \%)$ respondents use electronic databases for finding relevant information, (34.66\%) respondents use electronic resources for career development and $(20.66 \%)$ of the respondents use electronic resources for other activities.

Contrary to the above, Ivwighreghweta and Onoriode's (2012) study in Nigeria, which used the descriptive research method disclosed that students' use of open access journals is still far from expected. However, Baro, Endouware and Ubogu (2011) found that amongst the medical students at Delta State University in Nigeria the majority of the students were not aware and did not use the e-information resources such as Medical Literature Analysis and Retrieval System Online (MedLINE), Health InterNetwork Access to Research Initiative (HINARI), Cumulative Index to Nursing and Allied Health Literature (CINAHL) and the Next Unit of Computing (NUC) virtual library as sources of information to retrieve materials related to medical literature.

Also, a Pakistan study by Majid, Hayat, Patel, and Vijayaraghavan (2012) found that an overwhelming majority (91\%) of the participating students were either 'mostly' or 'always' using web search engines for acquiring the needed information. This implies that the use of the internet is high, but students may be using unevaluated resources or may be using the internet for other purposes other than academic purposes.

Kinengyere (2007) also carried out a study in Uganda to find out the effect of information literacy on the utilisation of electronic databases in selected academic and research institutions and found out that some of the available databases had not been utilized at all. That is users were not aware of the availability of such resources, they did not know how to access them, nor did they know what the resources offered. Another study in Uganda revealed that usage of e-electronic health information resources was low and that there was a significant relationship between usage and information literacy (Kinengyere, Kiyingi \& Baziraake, 2012). A similar study in Uganda confirmed these findings and reasoned that the frequency of use of these resources indicated that a lot needs to be done to increase e-resource usage (Gakibayo, Ikoja-Odongo \& Okello-Obura, 2013).

In Malawi, Mawindo \& Hoskins (2008) also noted that "only a few electronic resources were actually used by the students", who "preferred 
websites over the scholarly academic databases and e-journals." Besides, a study in Dhaka, Bangladesh to investigate access and usage of scholarly electronic journals (e-journals) at Dhaka University Library (DUL) reported that there is a growing interest in e-journals usage among the users at DU (Islam, Alam \& Sultana, 2011).

\section{Preferred resources utilized mostly by undergraduate}

Lee, Paik \& Joo (2012) confirms that a variety of factors influence the selection of information sources. Lee et. al. (2012) affirm that university students preferred online sources in their academic searches. A study by Quigley, Peck, Rutter \& Williams (2002) on factors in the selection of information resources among science faculty at the University of Michigan shows that $67.3 \%$ of the respondents preferred print journal resource among the four most frequently selected resources.

A study by Naqvi (2012) indicates that e-resources such as AGRIS, AGRICOLA, CAB abstract, agriculture \& natural resources were highly used among the postgraduate students and research scholars. Also, it was realised that in Malaysia an increase in the simple awareness of online databases among library users underscoring the relevant databases for the respective faculty attest to be useful in bringing about an increase in the usage of their online databases (Janaki \& Mohamed, 2007). However, in Baltimore it was found that undergraduate students depended predominantly on the internet sites and online instruction modules such as Blackboard or WebCT when it comes to their research instead of the university-funded research sources (Van Scoyoc \& Cason, 2006).

A study by Togia \& Tsigilis (2010) found that the vast majority of their participants used Internet search engines rather than specialised databases and full-text resources. It is quite interesting, that nearly half of the respondents $(49.1 \%)$ had never used ERIC, the fundamental resource of education literature. The underutilization of e-information resources has also been highlighted by Rehman and Ramzy (2004), who studied health care professionals at the Health Science Center of Kuwait University. They found that Medline was the most heavily used sources, followed by electronic journals.

Narrowing the analysis down to the Ghanaian perspective, Dadzie (2005) found that the vast majority of students, she surveyed preferred to search, search engines like Google and Yahoo, while very few of them make use of the OPAC and the electronic databases the library subscribes to. However, seven years down the line, contrary to Dadzie's findings, an unpublished work carried out by Apenteng-Obese (2012) revealed that out of the total number of students surveyed the majority of the students knew of electronic databases which to them constitute the e-resources available to the 
University of Ghana Dental School (UGDS) library. The study further revealed that most library users were aware of e-resources through their colleagues or friends and not through the library orientation or library staff to use electronic databases. This implies that seven years down the road there has been a paradigm shift among students as far as the use of e-databases are concerned.

\section{Perception of students towards the usage of information resources for their academic work}

The perception of library clients about library resources is of extreme significance on the grounds that to a huge degree it decides the level of information resources usage in academic libraries.

A study by Omeluzor, Akibu \& Akinwoye (2016) revealed four issues relating to perception of students towards the usage of information resources. They found that students strongly perceive e-resources in their study area to be insufficient and as such the Internet sites and other database are better than the library subscribed e-resources. Electronic Resources are not well structured and finally searching through the computer system for e-book and e-journal is time consuming. The second finding is similar to what Odongo \& Okello-Obura (2013) found which is that students perceive Internet searches to be easier than the subscribed e-resources

Likewise, Epic (2001) stated that many people first go to a general Internet search engine such as Google and do a keyword search than library subscribed e-resources. Bamidele et al., (2013) believes that the perception of certain resources in the library depends on users' awareness, packaging, format it is presented in, ease of use, result oriented and role of the tutor. Swain (2010) pointed out that perception could be influenced by the interest and exposure that a user or a student has in the database, while perception encourages the users to utilize library resources.

\section{Materials and methods}

Central University was conveniently selected for the study with a population of 8,400 . The study adopted a cross-sectional survey approach to examine, perception, use and preferences of information resources among Central University undergraduate students. The study population comprised 200-400 level students. All 200-400 level students were selected because the researcher believed they had been in school for a while and were used to the library and information resources available. A statistical table was used to determine the sample frame and size resulting with a sample size of 370 with a confidence level of $95 \% .375$ questionnaires were issued out; only 236 were returned and used for analysis. 
Purposive sampling was employed in the selection of respondents until the last respondent was reached. This was based on Brink (1996) assertion that purposive sampling relies on the judgment of the researcher regarding subjects who are representative of the phenomenon or topic being studied, or who are especially knowledgeable about the question at hand. The instrument used to collect data was self-administered questionnaires which were distributed to the respondents. The questionnaire consisted of open and closed-ended questions outlined under four sections. The researchers were supported by two students to administer the questionnaire. Data generated for the study was analysed using the Statistical Package for Service Solution (SPSS) version 21 from which descriptive and inferential statistics were computed

\section{Results and Discussions \\ Demographics}

The study adopted a cross-sectional survey approach to examine, perception, use and preferences of electronic and print resources among Central University undergraduate students.

The total breakdown of respondents is shown in table one below;

Table 1: Demographics

\begin{tabular}{ccc}
\hline Level & Frequency & Percent \\
\hline 200 & 117 & 49.9 \\
300 & 99 & 41.6 \\
400 & 20 & 8.5 \\
Total & $\mathbf{2 3 6}$ & $\mathbf{1 0 0 . 0}$ \\
\hline
\end{tabular}

Sources: field study, 2017

\section{Information Resources utilized by the undergraduate students}

Table 2 shows that majority of the respondents 85(36.2\%) rarely use eresources. 177(49.9\%) always use print resources in the library, 68 (28.9\%) indicated that they did not use e-books in the library, and the last group of respondents 143(60.9\%) agreed that they always use the reports in the library.

The desire to choose between electronic and print resources is dependent on the circumstance in which student find themselves. For instance, users prefer using electronic resources when they need to do research remotely, when they need access to quick information, or when assignments require upto-minute information. However, when users need detailed and serious sources for major assignments, or when they require immediate help from a librarian, they will rather fall on print resources. Dilevko and Gottlieb (2002) also found that undergraduate students prefer electronic resources over their print equivalents when they want to cut and paste quotations directly into their essays.

Table 2: Usage of Information Resources 


\begin{tabular}{|c|c|c|c|c|c|c|c|c|}
\hline & E-Resources & \multicolumn{2}{c|}{$\begin{array}{c}\text { Print } \\
\text { Resources }\end{array}$} & \multicolumn{2}{c|}{ E-Books } & \multicolumn{2}{c|}{ Reports } \\
\hline & Freq. & $\mathbf{\%}$ & Freq. & \% & Freq. & \% & Freq. & $\%$ \\
\hline Always & 14 & 6.0 & 117 & 49.9 & 24 & 10.2 & 143 & 60.9 \\
\hline Often & 10 & 4.3 & 53 & 22.7 & 33 & 14.0 & 58 & 24.7 \\
\hline Rarely & 85 & 36.2 & 46 & 19.5 & 68 & 28.9 & 0 & 0 \\
\hline Never & 49 & 20.9 & 19 & 8.1 & 75 & 31.9 & 0 & 0 \\
\hline Total & 236 & 100 & 236 & 100 & 236 & 100 & 236 & 100 \\
\hline
\end{tabular}

\section{Preferred resource format}

The researchers asked additional questions pertinent to the information resource format that the respondents preferred to use for their academic work. This research question sought to know the preferred resource format respondents often accessed for academic purposes, whether print resources or the electronic resources. It also sought to find out whether students were accessing the library's subscribed online databases. Table 3 indicated that the majority $134(57.0 \%)$ of the respondents always preferred print resource formats for their academic work while 101(43\%) occasionally preferred the electronic resource formats for academic work. This implies that the demand for print resources format is very high among central university undergraduate students.

Table 3. Preferred resource format

\begin{tabular}{ccc}
\hline Parameter & Frequency & Percent \\
\hline & & \\
Print & 134 & 57.0 \\
Electronic & 101 & 43.0 \\
Total & $\mathbf{2 3 6}$ & $\mathbf{1 0 0 . 0}$ \\
\hline
\end{tabular}

Sources: field study, 2017

\section{Why patrons use preferred resources}

The researchers also attempted to discern why respondents used their preferred information resources. Among the answer choices included on the survey were: accessibility, completeness, ease of use, accuracy and currency (Table 3). Majority of the respondents $118(50.2 \%)$ preferred print resources because of its accessibility, 107(45.3\%) agreed that print resources was complete in itself, while 147(63.6\%) asserted that they found it easy to use their preferred resources. In terms of accuracy majority of the respondents $115(48.9 \%)$ agreed print resources were more accurate than its counterpart.

Participants in another study also report that print documents not only facilitate annotations, but also enable easier comparisons to be made among all gathered sources (Dilevko \& Gottlieb, 2002). Marshall (1997) notes that "support for a smooth integration of annotating with reading is the most 
difficult to interpret from a design point of view; yet, it is potentially the most important." It is very likely that people will continue to print out electronic documents for annotation, even as they read materials in a digital library (Marshall, 1997).

Table 4. Why patrons use preferred resources

\begin{tabular}{|c|c|c|c|c|c|c|c|c|c|c|}
\hline & \multicolumn{2}{|c|}{ Accessibility } & \multicolumn{2}{c|}{ Completeness } & \multicolumn{2}{c|}{ Ease to use } & \multicolumn{2}{c|}{ Accuracy } & \multicolumn{2}{c|}{ Currency } \\
\hline & $\begin{array}{c}\text { Freq } \\
\text { - }\end{array}$ & $\mathbf{\%}$ & $\begin{array}{c}\text { Fre } \\
\mathbf{q .}\end{array}$ & $\mathbf{\%}$ & Freq. & $\mathbf{\%}$ & $\begin{array}{c}\text { Fre } \\
\mathbf{q .}\end{array}$ & $\mathbf{\%}$ & $\begin{array}{c}\text { Fre } \\
\mathbf{q .}\end{array}$ & $\mathbf{\%}$ \\
\hline $\begin{array}{c}\text { Strongly } \\
\text { Agree }\end{array}$ & 118 & 50.2 & 62 & 26.4 & 147 & 63.6 & 45 & 19.1 & 54 & 23.0 \\
\hline Agree & 85 & 36.0 & 107 & 45.3 & 47 & 20.3 & 115 & 48.9 & 86 & 36.6 \\
\hline Neutral & 15 & 6.4 & 54 & 23.0 & 20 & 8.7 & 45 & 19.1 & 52 & 22.1 \\
\hline Disagree & 7 & 3.0 & 2 & 0.9 & 2 & .9 & 20 & 8.5 & 33 & 14.0 \\
\hline $\begin{array}{c}\text { Strongly } \\
\text { Disagree }\end{array}$ & 10 & 4.3 & 10 & 4.3 & 15 & 6.5 & 10 & 4.3 & 10 & 4.3 \\
\hline Total & 236 & 100 & 236 & 100 & 236 & 100 & 236 & 100 & 236 & 100 \\
\hline
\end{tabular}

Sources: field study, 2017

\section{Implications and conclusion}

This study examined the perception, usage and preferences of electronic and print resources among undergraduate students in Central University. As shown above, students were more inclined towards using print resources than e-resources. However, considering the amount of money, time, and resources that the university spends in getting the e resources, and in training staff to assist the students with its use, this trend is quite worrisome. Again, if the subscription of e-resources is the solution to the lack of space and cuts off the risk of students acquiring stale knowledge then they stand the chance of losing out modern findings which might benefit them in the long run. Users desire a crossbreed information atmosphere in which electronic information sources does not totally replace information in print but supplements it, adds new access and opportunities for users to choose. Electronic and print resources have their distinctive advantages and boundaries; therefore, at best students need to be encouraged to use both in order to acquire more detailed and current updates in any field of study. In this way, they will satisfy the information needs of users in different circumstances.

Again, electronic resources offer a wide range of new access opportunities that are absent in the traditional environment, including remote access, 24//7 access, and multiple users for single sources. So, its neglect completely, becomes a limitation to their progression in academia. Whilst saying this, we should also not forget the issue of internet access which seems to be the problem faced by most students. The fieldwork indicated that accessibility, accuracy, and ease of use were the most dominant challenges 
students faced and therefore should be looked at very carefully. If students are guaranteed access to the internet at a click of the button, the use of e-resources would come easy and more convenient to them.

Lastly, our own limitations which include the geographical limitations and small sample size means that the results cannot be generalized across other institutions. Many respondents in this survey are residential students, which may most likely affect their preferences for and use of print and electronic resources. Studies in other geographical regions are needed to fully validate the findings. It should also be noted that current crop of students are growing with new technologies and is likely to have different expectations and preferences toward the choice of electronic resources and traditional resources.

Furthermore, technologies are constantly improving, which may have an impact on student's satisfaction with reading electronic documents. Future studies are needed to continually monitor the changes in student's perceptions and preferences, and their resultant impact on the use of print and electronic resources.

\section{References}

1. Bamidele, I. A., Omeluzor, S. U., \& Amadi, H. U. (2013). Utilization of Journal Publications by Undergraduate Students of Babcock University, Nigeria. Library Philosophy and Practice, 0_1.

2. Bhat, I., \& Mudhol, M. V. (2014). Use of e-resources by faculty members and students of Sher-E-Kashmir Institute of Medical Science (SKIMS). DESIDOC Journal of Library \& Information Technology, 34(1).

3. Corlett-Rivera, K., \& Hackman, T. (2014). E-book use and attitudes in the humanities, social sciences, and education. Portal: Libraries and the Academy, 14(2), 255-286.

4. Cumaoglu, G., Sacici, E., \& Torun, K. (2013). E-book versus printed materials: preferences of university students. Contemporary educational technology, 4(2), 121-135.

5. Dadzie, P. S. (2005). Electronic resources: access and usage at Ashesi University College. Campus-Wide Information Systems, 22(5), 290297.

6. Dhanavandan, S., Mohammed Esmail, S., \& Nagarajan, M. (2012). Use of electronic resources at Krishnasamy College of Engineering \& Technology Library, Cuddalore.

7. Dilevko, J., \& Gottlieb, L. (2002). Print sources in an electronic age: A vital part of the research process for undergraduate students. Journal of Academic Librarianship, 28(6), 381-392. 
8. Epic (2001). The use of electronic resources among undergraduate and graduate students. Available at: http://www.epic.columbia.edu/eval/find03.html

9. Gakibayo, A., Ikoja-Odongo, J. R., \& Okello-Obura, C. (2013). Electronic information resources utilization by students in Mbarara university library.

10. Hadebe, T., \& Hoskins, R. (2010). Information seeking behaviour of master's students using library electronic databases in the Faculty of Humanities, Development and Social Sciences of the University of KwaZulu-Natal. Innovation, 40(1).

11. Hammed, A. B., \& Osunrinade, O. A. (2010). Students' perception and utilization of serial materials in the Polytechnic Ibadan Library, Nigeria. Journal of Research in Education and Society, 1.

12. Hampton-Reeves, S., Mashiter, C., Westaway, J., Lumsden, P., Day, H., Hewertson, H., \& Hart, A. (2009). Students' use of research content in teaching and learning. Preston, United Kingdom: Center for Research-Informed Teaching, University of Lancashire.

13. Ingutia-Oyieke, L., \& Dick, A. L. (2010). A comparative analysis of the use of electronic resources by undergraduate students at two Kenyan universities.

14. International Federation of Library Associations and Institutions (2012) Viewed on May 30 2017, http://lib.hku.hk/cd/policies/erp.html

15. Ivwighreghweta, O., \& Onoriode, O. K. (2012). Use of open access journals by lecturers at Western Delta University, Oghara, Nigeria. Library Philosophy and Practice, 1522-0222.

16. Janaki, S., \& Mohamed, P. (2007). The Use of Subscribed Online Databases among the Postgraduates at the University of Malaya Library.

17. Kinengyere, A. A., Kiyingi, G. W., \& Baziraake, B. B. (2012). Factors affecting utilisation of electronic health information resources in universities in Uganda.

18. Lee, J.Y., Paik, W. \& Joo, S. (2012). Information resources selection of undergraduate students in academic search tasks. Information Research. 17 (1). Retrieved from http://informationr.net/ir/171/paper511.html

19. Lwehabura, M. J. F. (2008). Skills and training needs for use of electronic information resources (EIRs) among students in four Tanzanian Universities. University of Dar Es Salaam Library Journal, 10(1-2).

20. Majid, S., Hayat, I., Patel, R. P., \& Vijayaraghavan, S. (2012). Information needs and seeking behaviour of business students. 
21. Marshall, C. C. (1997). Annotation: From paper books to the digital library. In Proceedings of the 2nd ACM international conference on digital libraries (pp. 131-140). Philadelphia, PA: ACM.

22. Mawindo, D., \& Hoskins, R. (2008). Use of Print and Electronic Resources by Students at the University Of Malawi College Of Medicine. Mousaion, 26(1).

23. Okello-Obura, C., \& Magara, E. (2008). Electronic information access and utilization by Makerere University students in Uganda. Evidence Based Library and Information Practice, 3(3), 39-56.

24. Omeluzor, S. U., \& Akinwoye, O. A. (2016). Students' Perception, Use and Challenges of Electronic Information Resources in Federal University of Petroleum Resources Effurun Library in Nigeria.

25. Rehman, S., \& Ramzy, V. (2004). Awareness and use of electronic information resources at the health sciences center of Kuwait University. Library Review, 53(3), 150-156.

26. Romanov, K., \& Aarnio, M. (2006). A survey of the use of electronic scientific information resources among medical and dental students. BMC Medical Education, 6(1), 1.

27. Sahin, Y. G., Balta, S., \& Ercan, T. (2010). The use of internet resources by university students during their course projects elicitation: a case study. TOJET: The Turkish Online Journal of Educational Technology, 9(2).

28. Shabani, A., Naderikharaji, F., \& Reza Abedi, M. (2011). Reading behavior in digital environments among higher education students: Analysis of demographic factors in Iran. Library Review, 60(8), 645657.

29. Swain, D. P. (2010). Students' keenness on use of e-resources. The Electronic Library, 28 (4): 580-591

30. Togia, A., \& Tsigilis, N. (2010). Awareness and use of electronic information resources by education graduate students: Preliminary results from the Aristotle University of Thessaloniki. In A. Katsirikou y C. H. Skiadas, Qualitative and quantitative methods in libraries: proceedings of the International Conference on QQML2009 (pp. 464472).

31. Van Scoyoc, A. M., \& Cason, C. (2006). The electronic academic library: Undergraduate research behavior in a library without books. Portal-Libraries and the Academy, 6(1), 47-58. 